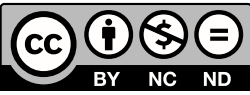

Estudos Teológicos foi licenciado com uma Licença Creative Commons Atribuição - NãoComercial - SemDerivados 3.0 Não Adaptada

http://dx.doi.org/10.22351/etv59i2.3487

\title{
Pentecostalismo: a religiosidade brasileira, OS PRINCÍPIOS DE UNIVERSALIZAÇÃO DE UMA RELIGIÃo E AFINIDADES ELETIVAS ${ }^{1}$
}

\author{
Pentecostalism: the Brazilian religiosity, the principles of universalization \\ of a religion and elective affinities
}

\section{Eduardo Leandro Alves ${ }^{2}$ Oneide Bobsin ${ }^{3}$}

Resumo: O objetivo deste texto busca considerar o tipo de catolicismo trazido pelos ibéricos para sua colônia, assim como a religiosidade de indígenas e negros escravizados, com vistas a identificar elementos religiosos preexistentes que foram ressignificados pelo pentecostalismo clássico. Nesse caminho utiliza-se o método da história comparada, sinalizando no desenvolvimento do pentecostalismo clássico as influências religiosas místicas da formação da sociedade brasileira. Busca-se identificar a presença dos princípios de universalização de uma religião em Clifford Geertz e seus possíveis desdobramentos na sociedade aliados à afinidade eletiva em Max Weber.

Palavras-chave: Pentecostalismo. Religiosidade popular. Universalização. Afinidade eletiva.

Abstract: The purpose of this essay is to evaluate the type of Catholicism that was brought by Iberians to their colony, as well as the religiosity of indigenous and black enslaved people. The religiosity of the colonizers, as it will be proven, was largely intolerant and bigoted. The path that has been used is Comparative History Method, signaling to the development of Classical Pentecostalism and the presence of principles of universalization of a religion as in Clifford Geertz and a probable repercussion in society, besides that to elective affinity in Max Weber.

Keywords: Pentecostalism. Popular religiosity. Universalization. Elective affinity.

1 O artigo foi recebido em 15 de janeiro de 2019 e aprovado em 21 de maio de 2019 com base nas avaliações dos pareceristas ad hoc.

2 Mestre. Faculdades EST, São Leopoldo, RS. E-mail: eduleandroalves@hotmail.com

3 Doutor. Faculdades EST, São Leopoldo, RS. E-mail: obobsin@est.edu.br 


\section{Introdução}

Este texto se propõe a discutir o crescimento do pentecostalismo clássico a partir da formação da sociedade brasileira. Nesse caminho os clássicos da antropologia, sociologia e literatura brasileira são de grande valia. Dentro dessa proposta está a busca da compreensão do movimento pentecostal no Brasil, que passa pelo entendimento da formação da própria sociedade brasileira, incluindo os colonizadores e suas influências.

Advoga-se que o crescimento do pentecostalismo clássico não ocorreu desassociado da formação da sociedade brasileira. A hipótese é que a teologia pentecostal clássica produziu uma ressignificação do "mundo espiritual”. Não há uma negação das realidades espirituais ativas no dia a dia do indivíduo, mas uma "reorientação" em tais crenças por meio da teologia cristã de vertente pentecostal.

\section{Os portugueses}

Os portugueses que vieram ao Brasil possuíam o objetivo de exploração econômica. Em sua maioria não foram famílias portuguesas que chegaram nas caravelas. Mas indivíduos dispostos a explorar a terra, retirar o máximo que pudessem. Devido à localização geográfica de Portugal e ao intenso trânsito de outras raças em seu território, como, por exemplo, mouros, árabes e negros, produziu pessoas menos avessas à mestiçagem. No território português esse contato com outras raças se deu por numerosas guerras e disputas por territórios. ${ }^{4}$ Essa "maior inclinação" à miscigenação era uma das características, além da religiosa, que os diferenciavam, por exemplo, dos holandeses, dos franceses que abarcaram no litoral brasileiro. No entanto, é necessário pontuar que essa miscigenação em terras brasileiras não se deu por consenso entre as raças, mas, na grande maioria dos casos, as índias e negras escravizadas eram violentadas gerando os filhos mestiços, o que mais tarde Darcy Ribeiro vai chamar de "ninguendade".

A localização geográfica de Portugal era um ponto de contato, de circulação, intercomunicação e de conflitos entre elementos diversos, quer étnicos, quer sociais. E o quase permanente estado de guerra contribuiu para que os portugueses que aqui chegaram com suas caravelas trouxessem em suas veias uma grande mistura étnica. Em sua maioria eram de descendência moura (africano) e europeia, mestiços. Vale também citar a influência romana que contribuiu para uma certa romanização ou latinização da Ibéria, visto que essa região era o limite ocidental do Império Romano.

4 FREYRE, Gilberto. Casa-grande e Senzala. 28. ed. Rio de Janeiro: Record, 1992. p. 266. O quase permanente estado de guerra em que viveu, por largos anos, Portugal, situado entre a África e a Europa, deu-lhe uma constituição social vulcânica que se refere no quente e plástico do seu caráter nacional, das suas classes e instituições, nunca endurecidas nem definitivamente estratificadas. $\mathrm{O}$ estado de conquista e reconquista, de fluxo e refluxo. Não deixou que se estabelecesse em Portugal nenhuma hegemonia, a não ser de momento. Nenhum exclusivismo - a não ser oficial ou superficial - de raça ou de cultura. 
O resultado disso foi uma cultura variada de mestiços. Cultura ora em harmonia, ora em conflito. ${ }^{5}$

Embora esse texto não tenha a pretensão de ser um estudo exaustivo da realidade sociorreligiosa de Portugal, é necessário ao menos olhar e reconhecer, por exemplo, a importância dos mouros ${ }^{6}$ em terras portuguesas. Visto que os mouros tiveram um papel de extrema influência na antropologia e na cultura portuguesa de uma maneira bem específica. Eram um povo cultural e antropologicamente diferente daquele encontrado na Europa.

A influência do povo africano mouro se dá por meio de uma série de efeitos, ora por meio de invasões, ora por meio da ação e do trabalho dos escravos sobre os senhores. Os mouros que estavam em meio aos portugueses eram em sua maioria árabes muçulmanos. Quando os povos árabes invadiam outros povos, sempre levavam consigo a sua religião, pois essa faz parte de sua antropologia e cultura. Essas raízes árabes foram trazidas para dentro da região Ibérica. Ali se espalharam de uma maneira sutil, mas profunda, gerando mudanças na cultura, religião, costumes e outros.

Ao contrário do que sucede em relação aos Romanos, aos Suevos, aos Visigodos, não é possível fixar num determinado número de anos, ou mesmo de séculos, a duração do domínio muçulmano na Península, porque essa duração variou muito de região para região. Nunca se chegou a exercer nas terras mais setentrionais; todo o país ao norte do Ebro estava de novo sob o domínio cristão em 809. O Porto e Braga foram reconquistados cerca de 868. Coimbra voltou definitivamente à posse cristã em 1064 e Lisboa em 1147. Em Sevilha, Córdova e Faro, os Mouros estiveram cerca de seis séculos (até aos meados do século XIII); de Granada só foram expulsos nos fins do século XV: a presença moura atinge perto de oito séculos. ${ }^{7}$

É esse sangue e essa cultura mista que vêm para o Brasil, havendo assim uma grande mistura de raças. $\mathrm{O}$ brasileiro não é europeu, nem indígena, muito menos o resultado do contato direto com os africanos escravizados. Isso explica o muito de mouro que persistiu na vida íntima do brasileiro no decorrer dos tempos, e que ainda

5 FREYRE, 1992, p. 268. Portugal é por excelência o pai do louro transitório ou do meio loiro. Nas regiões mais penetradas de sangue nórdico, muita criança nasce loura e cor-de-rosa, para tornar-se mais tarde morena e de cabelo escuro. Ou então - o que é mais característico - revela-se uma dualidade, o equilíbrio de antagonismo: homens de barba loura e de cabelo escuro. Homens morenos de cabelo louro.

6 Os mouros eram os descendentes dos antigos muçulmanos que permaneceram na Espanha e em Portugal. Após a Reconquista, diante das alternativas de conversão ao catolicismo ou emigração, optaram pela conversão, embora conservassem a língua, os costumes e, secretamente, a religião. Em Portugal do século XVI havia até uma confraria católica de mouriscos, escravos ou forros, que nos revela que o sincretismo nasce de um cripto islâmico, forçada pela inquisição. RIBAS, Rogério de Oliveira. Festa e Inquisição: Os Mouriscos na Cristandade Portuguesa dos Quinhentos. In: JANCSÓ, István; KANTOR, Iris (Orgs.). Festa: Cultura e Sociablidade Portuguesa. São Paulo: Hucitec; Editora da Universidade de São Paulo; Fapesp: Imprensa Oficial, 2001. v. 1, p. 204-210.

7 SARAIVA, José Hermano. História concisa de Portugal. Lisboa: Publicações Europa-América, 1984. (Coleção Saber). p. 33. 
hoje é encontrado nas mais diversas áreas de nosso dia a dia, na cultura, nas práticas religiosas e outros. ${ }^{8}$

\section{A religião dos portugueses}

Portugal era um lugar de trânsito contínuo de diferentes culturas, que influenciaram diversas áreas da vida do português. Isso também ocorreu com relação à sua religiosidade. Sua maneira de viver e expressar a fé sofreu influências dos diversos povos que transitaram pela região.

Como sucedeu muito mais tarde com os judeus, os Mouros queixavam-se de que muitos cristãos fingiam que se convertiam, mas ficavam cristãos por dentro. De resto, a conversão não era obrigatória; a mesquita e a igreja continuavam abertas e não demorou muito tempo que os ex-cristãos não verificassem que a diferença entre os adeptos do Evangelho e os do Corão não era tão grande como eles tinham pensado; na verdade, os Mouros tratavam com desprezo e constantes injustiças os convertidos. ${ }^{9}$

O historiador Luís Câmara Cascudo relata algumas superstições/crendices, assim como gestos e expressões que migraram para a sociedade brasileira, que são originárias dos povos mouros.

Há uma superstição curiosa e ainda viva e respeitada entre brasileiros e mesmo em gente moça de cidade grande. Não entrar pela porta por onde saiu e não sair pela porta por onde entrou. A exigência acentua-se nas visitas às casas amigas, onde a intimidade permite o livre exercício da crendice. É espantosamente antiga. Veio da Arábia através da posse moura e árabe na Espanha e Portugal. No ano de 611, o profeta Maomé combatia esse hábito pré-islâmico, arraigado nas populações pagãs do século VII. Os peregrinos à Meca, voltando para casa, faziam abrir uma abertura no muro posterior da residência por onde entrassem. Pela porta principal, por onde haviam saído, não ousavam penetrar. Maomé deixou uma alusão expressiva na surata da Vitela $(11,185)$, tentando fazer desaparecer essa reminiscência herética, do tempo em que a Caaba de Meca hospedava 360 ídolos ou fetiches das tribos árabes. [...] No fim do século XX deparamo-la, íntegra, numa das maiores cidades do Brasil. ${ }^{10}$

A religião de Maomé vai influenciar o cristianismo português de uma maneira muito profunda. Essa influência vai gerar em Portugal um cristianismo humano e lírico (romântico). Esse elemento estará presente no culto aos santos, ao Menino Jesus e à Virgem Maria. Reportando sempre no cristianismo português uma certa presença de fantasia, sonho, um devaneio romântico, muitas vezes, até sensual. Esse amor ou o desejo humano conservou no cristianismo encontrado na Europa um certo "gosto de carne".

8 FREYRE, 1992, p. 272.

9 SARAIVA, 1984, p. 36.

${ }^{10}$ CÂMARA CASCUDO, Luiz. Mouros, judeus e franceses. Rio de Janeiro: Perspectiva, 1984. p. 28. 
Cristianismo em que o menino Deus se identificou com o próprio Cupido e a Virgem Maria e os Santos com os interesses de procriação, de geração e de amor mais do que com os de castidade e de ascetismo. Este ponto o cristianismo português pode-se dizer que excedeu ao próprio maometanismo. Os azulejos, de desenhos assexuais entre os maometanos, animaram-se de formas quase afrodisíacas nos claustros dos conventos e nos rodapés das sacristias. De figuras nuas. De meninozinhos-Deus em que as freiras adoraram muitas vezes o deus pagão do amor de preferência ao Nazareno triste e cheio de feridas que morreu na Cruz. ${ }^{11}$

A influência do islamismo parece que, favorecida pelo clima doce e afrodisíaco de Portugal, gerou um cristianismo de grande intimidade entre o devoto e o santo. Uma mistura entre o sacro e o profano. Gilberto Freyre faz uma análise interessante:

É Nossa Senhora do Ó adorada na imagem de uma mulher prenhe. É São Gonçalo do Amarante só faltando tornar-se gente para emprenhar as mulheres estéreis que o aperreiam com promessas e fricções. É São João Batista festejado no seu dia como se fosse um rapaz bonito e namorador, solto entre as moças casadouras $[\ldots]^{12}$.

O santo passou a ser tratado como alguém da família, davam-lhe atributos humanos de rei, rainha, de pai e mãe, de filho e namorado. Cada santo estava ligado com as diferentes fases da vida doméstica e íntima da família, do lugarejo, da vila etc.

Havia também na cultura religiosa portuguesa os santos "regionais". Ou seja, cada lugarejo tinha o seu santo específico, que muitas vezes, estava identificado com a história do lugar; para esse santo eram realizadas festas, procissões, promessas. Esse santo era o seu "padroeiro", aquele que a protegia e garantia tranquilidade de vida.

Muitos dos elementos encontrados no catolicismo português estão presentes até hoje no catolicismo brasileiro. A maneira pela qual os santos são vistos, as práticas religiosas, a maneira popular de viver a sua espiritualidade são prova disso. Essa devoção quase cega, na qual o santo é tratado como alguém que faz parte da história da família, e outros elementos como promessas e procissões fazem parte do cotidiano religioso do brasileiro.

Nenhum resultado mais interessante dos muitos séculos do contato do cristianismo com a religião islâmica - contato que tantas vezes se mostrou em rivalidade - que o caráter militar tomado por alguns santos no cristianismo português e mais tarde no Brasil. Santos milagrosos como Santo Antônio, São Jorge e São Sebastião foram, entre os devotos, sagrados capitães ou chefes militares como qualquer poderoso senhor de engenho. Nas procissões, carregavam-se outrora os andadores dos santos como a grandes chefes que tivessem triunfado em lutas ou guerras. ${ }^{13}$

${ }^{11}$ FREYRE, 1992, p. 272.

12 FREYRE, 1992, p. 288.

13 FREYRE, 1992, p. 288. 


\section{A catequização dos indígenas e dos negros}

O descobrimento do Brasil enquadra-se no grande programa marítimo e comercial inaugurado pela viagem de Vasco da Gama. Os portugueses chegaram e trouxeram a história dentro de sua bagagem. Aqui aplicaram os mesmos métodos aplicados no próprio Portugal, no território reconquistado dos mouros. Eram métodos de autocolonização aristocrática e agrária. ${ }^{14}$

Antes de aplicar os seus métodos de colonização na América, os europeus foram colocados frente a frente com populações que viviam sob outros costumes e exibiam traços físicos peculiares, bem diferentes dos seus. Longos debates foram traçados para determinar se os nativos eram ou não humanos e partindo de critérios religiosos analisou se possuíam alma ou não. Os portugueses atribuíram certa ingenuidade aos índios, a qual aparece na carta de Pero Vaz de Caminha, conforme texto de Roberto Damatta:

A feição deles é serem pardos, um tanto avermelhados, de bons rostos e bons narizes, bem feitos. Andam nus, sem cobertura alguma. Nem fazem mais caso de encobrir suas vergonhas do que mostrar a cara. Acerca disso são de grande inocência. Parece-me gente de tal inocência que se nós entendêssemos a sua fala e eles a nossa, seriam logo cristãos, visto que não têm nem entendem crença alguma, segundo aparências ${ }^{15}$.

Por vezes eram retratados por cronistas como ingênuos, afáveis, corajosos, infantis, bonitos, virtuosos e inocentes, vivendo uma existência pacífica e ordeira. E por vezes apareciam como bárbaros, estúpidos, selvagens, feios, atrasados, preguiçosos, comedores de gente e de carne crua, falavam uma língua ininteligível e viviam na orgia e devassidão. Com os portugueses veio também a religião, que foi imposta como única. Em consequência disso, os povos indígenas foram impregnados por uma nova religião.

Os indígenas brasileiros eram animistas ao cultuar o sol, a lua, as estrelas, os animais, as plantas e tudo que lhes circundava o cotidiano. O animismo é sensível aos augúrios e presságios oriundos da natureza, como o uivo de uma onça, presença de uma cobra ou de certas aves. $\mathrm{O}$ animismo atribui alma aos animais, que, como os seres humanos, voltam à Terra para resgatar carmas. Sobre o animismo existem teorias

14 FREYRE, 1992, p. 255ss. A descoberta do Brasil coincidiu com a reconquista da península Ibérica, após sete séculos de domínio mouro. Assim, as histórias das recentes batalhas contra os islâmicos - também chamados de mouros e de sarracenos - foram trazidas pelos colonizadores e reproduzidas em forma de cantos e histórias que, com o passar do tempo, transformaram-se em lendas. Reflexos dessa tradição estão presentes, em vários pontos do Brasil, nas “cavalhadas" ou "corridas de argolinhas", torneios de habilidade entre cavaleiros vestidos de azul, representando os cristãos, e de vermelho, no papel de mouros. Essas manifestações são comuns principalmente no Nordeste e nos estados de Goiás e de Minas Gerais.

15 DAMATTA, Roberto. O que faz do Brasil, Brasil? 11. ed. Rio de Janeiro: Rocco, 2000. p. 46ss. 
etnográficas, sociológicas e psicológicas, mas todas acabam ligando as manifestações animistas a um estágio cultural dos povos. ${ }^{16}$

Quando portugueses e espanhóis chegaram, encontraram um povo que, segundo eles, precisava ser civilizado e catequizado por meio da doutrina e da espada. Como figura de destaque dessa época temos Bartolomeu de las Casas, e outros monges que se revoltaram com a opressão sofrida pelos primeiros habitantes das Américas. ${ }^{17}$

Na compreensão de Darcy Ribeiro, a identidade do brasileiro teria surgido a partir do estranhamento, sobretudo com relação aos europeus:

É bem provável que o brasileiro comece a surgir e a reconhecer-se a si próprio mais pela percepção de estranheza que provocava no lusitano do que por sua identificação como membro das comunidades socioculturais novas, porventura também porque desejoso de remarcar sua diferença e superioridade frente aos indígenas ${ }^{18}$.

Assim, o brasilíndio, ou mameluco, da mesma forma que o afro-brasileiro, etnicamente falando vivia em uma terra de ninguém, partindo dessa carência essencial, buscam livrar-se da ninguendade de não índios, não europeus e não negros, se veem forçados a criar a sua própria identidade étnica: a brasileira. ${ }^{19}$ Sentindo-se excluídos por seus ascendentes, não podendo compartilhar de sua identidade, foram obrigados a criar algo novo. Essa compreensão defende que a mestiçagem intensa no Brasil, ao criar homens e mulheres desenraizados, foi a propulsora de uma nova identidade e o elemento essencial para criar o povo novo brasileiro:

O surgimento de uma etnia brasileira, inclusiva, que possa envolver e acolher a gente variada que aqui se juntou, passa tanto pela anulação das identificações étnicas de índios, africanos e europeus, como pela indiferenciação entre as várias formas de mestiçagem, como os mulatos (negros com brancos), caboclos (brancos com índios) ou curibocas (negros com índios) ${ }^{20}$.

\section{Os negros}

A busca de mão de obra, a exploração da costa da África e das Américas pelos portugueses e espanhóis, no século XV, e sua colonização nos três séculos seguintes incrementaram consideravelmente o comércio moderno de escravos.

\footnotetext{
16 RIBEIRO, Darcy, O povo Brasileiro - formação e o sentido do Brasil. São Paulo: Companhia das Letras, 1995. p. 50.

17 BRAGATO, Fernanda. Raízes históricas dos direitos humanos na conquista da América: o protagonismo de Bartolomé de Las Casas e da Escola de Salamanca. Revista do Instituto Humanitas Unisinos, São Leopoldo, v. 487, 2016. Disponível em: <http://www.ihuonline.unisinos.br/index.php?option=com_co ntent\&view=article\&id=6495\&secao=487>. Acesso em: 02 fev. 2019.

18 RIBEIRO, Darcy. Os Brasileiros: Livro I - Teoria do Brasil. Petrópolis: Vozes, 1978. p. 114.

19 RIBEIRO, 1978, p. 118.

${ }^{20}$ RIBEIRO, 2006, p. 119.
} 
A escravidão desenvolveu-se em solo brasileiro em função da estrutura econômica e social do regime colonialista reinante à época. A princípio os índios foram a mão de obra escrava mais usada. No entanto, com o passar do tempo, os portugueses perceberam que a mão de obra indígena não era eficaz para os objetivos de exploração econômica vigente. Buscou-se uma mão de obra que atendesse a tais demandas de exploração empreendida pelos portugueses.

Por volta do ano de 1550 foram trazidos à força ao Brasil os primeiros negros escravizados vindos do continente africano. Em todo o período colonial, o tráfico negreiro foi a atividade importadora mais lucrativa do comércio exterior brasileiro. Calcula-se que cerca de três milhões de negros escravizados, de diversas etnias, foram absorvidos pelo cultivo do açúcar, do fumo e do algodão, pela economia mineradora e pelo serviço doméstico. ${ }^{21}$

Para a tranquilidade das consciências cristãs e como justificativa para a escravidão, nada melhor do que acreditar que os negros pudessem ser mantidos em cativeiros. Os negros eram comparados aos "macacos de um jardim zoológico", seres embrutecidos, estúpidos, bestiais, povo amoral, sem alma e objeto sem valor. ${ }^{22}$

Para a elite dominante da época, amparado pela religiosidade vigente, a escravidão representava uma instituição natural, uma obra de Deus, útil e necessária, tanto para os escravos quanto para os senhores. O senhor escravagista não se sentia ameaçado ou culpado por estar submetendo outro ser humano ao trabalho escravo. Mas, pelo contrário, ele via o negro como seu complemento natural. Enquanto esse se dedicava ao trabalho duro, complementava as atividades de seu senhor, dando a este a possibilidade de se dedicar às suas atividades que seriam as do espírito. Quanto à escravidão, diz-se que ela foi o eixo articulador da vida colonial, prolongando-se como a grande característica da sociedade brasileira do século XIX, impregnando com sua presença a organização econômica, os padrões materiais e morais. ${ }^{23}$ Proprietários e escravos eram, na prática, as únicas classes. ${ }^{24}$

Esses negros escravizados que aqui chegaram trouxeram consigo da África as suas raízes, seus costumes, sua religião, que era tribal, e, em certa parte, com fortes influências muçulmanas. Ao chegarem ao Brasil, esses negros foram proibidos por seus senhores de praticar seus costumes religiosos. No entanto, o fator que prevaleceu foi o de substituição, em que as entidades religiosas africanas passaram a receber nome de santos católicos, havendo somente uma substituição de nomes e valores. Esse método

${ }^{21}$ MOURA, Clóvis. Os quilombos e a rebelião negra. São Paulo: Brasiliense, 1987. p. 10.

${ }^{22}$ FREYRE, 1992, p. 304ss. O escravo vivia nas senzalas, quase sempre com excesso de trabalho e em condições precárias de higiene e salubridade, o que reduzia a expectativa de vida útil a cerca de sete anos nas áreas do açúcar e do ouro. A mentalidade escravocrata era muito difundida na colônia e no império, provocando a desvalorização do trabalho manual e a presença do escravo em quase todas as atividades, como a extração de diamantes, a lavoura do tabaco, o artesanato, o trabalho doméstico.

23 PRADO, J. Caio. Formação do Brasil Contemporâneo. Colônia. 10. ed. São Paulo: Brasiliense, 1992. p. 269ss.

24 MOURA, 1987, p. 11. 
de assimilação intensificou o grande processo sincretista ${ }^{25}$ religioso presente até hoje no Brasil.

\section{O sincretismo religioso}

Os portugueses realizaram a expansão ultramarina sob a cruz de Cristo. Em seus barcos seguiram muitos eclesiásticos. Com Pedro Álvares Cabral chegaram ao Brasil os primeiros franciscanos. Os navegantes, ao integrarem a terra à Coroa portuguesa, entregaram-na também ao cristianismo. Cristianismo este que havia sido influenciado pela religiosidade popular muçulmana no período de dominação moura na península Ibérica.

A intensa miscigenação ocorrida entre negros, brancos e indígenas, e o peso demográfico dos primeiros fizeram com que fosse muito grande a influência étnica das culturas de origem africana no Brasil. Essa se refletiu na língua, na música, na culinária, na religião e nos costumes.

Os negros introduzidos no Brasil pertenciam a civilizações diferentes e provinham das mais variadas regiões da África. Porém, suas religiões estavam ligadas a certas formas de famílias ou de organização clânica, a meios biogeográficos especiais, floresta tropical ou savana, estruturas aldeãs e comunitárias. O tráfico negreiro violou tudo isso, e o escravo foi obrigado a se incorporar, querendo ou não, a um novo tipo de sociedade com base na família patriarcal, no latifúndio, no regime das castas étnicas. ${ }^{26}$

O negro acabou se apegando à sua própria fé no esforço de encontrar um consolo diante de seu triste destino, misturando, como forma de resistência, a religião católica e a que trouxeram de sua terra natal. Vários aspectos de sua cultura e religião se mantiveram da mesma forma. Ou seja, o negro escravizado, inculturado numa comunidade, permaneceu ele mesmo; na sua identidade original permaneceram traços que estarão presentes até a morte.

${ }_{25}$ Reconhecemos as discussões sobre os termos sincretismo e hibridismo e a dificuldade de se chegar a um consenso. De forma simples, pode-se dizer que o sincretismo é mais atrelado a questões simbólicas da religião e o hibridismo um conceito mais abrangente da cultura como um todo. Maiores informações: BURKE, Peter. Hibridismo Cultural. São Leopoldo: Unisinos, 2006. Artigos interessantes podem ser vistos, por exemplo: SILVA, Rosilene da Conceição. Sincretismo religioso e hibridismo cultural: caminhos para a afirmação da religiosidade afro-brasileira. Revista da Associação Brasileira de Pesquisadores/as Negros/as (ABPN), [S.1.], v. 2, n. 5, p. 13-18, out. 2011. Disponível em: <http://www.abpnrevista.org.br/ revista/index.php/revistaabpn1/article/view/336>. Acesso em: 25 out. 2018.

26 BATISDE, Roger. As religiões africanas no Brasil. São Paulo: Pioneira, 1971. p. 30. Um texto clássico que aborda o sincretismo religioso na sociedade brasileira é a tese de doutorado de Roger Bastide (pesquisador francês que foi professor na USP no século passado) e publicado no Brasil em 1971 sob o título: As religiões africanas no Brasil. Em Batisde pode-se perceber uma formulação e sistematização daquilo que em Freyre aparece muitas vezes de forma implícita, como é o caso do conceito de sincretismo religioso e de democracia racial. Artigo interessante sobre a obra de Batisde: GODOY, João Miguel Teixeira; CARVALHO, Maria Gabriela de: Roger Bastide e a abordagem acadêmica da vida religiosa no Brasil. Revista caminhando, v. 20, n 1, p. 65-88, jan./jun. 2015. 
Rubem César Fernandes argumenta que as instituições oficiais no período da colonização tinham pouca penetração na sociedade que se formava no país. A igreja, assim como o estado, era um corpo centralizado na metrópole, que perdia densidade à medida que se espalhava pelos territórios coloniais. ${ }^{27}$ Essa fragilidade institucional caracteriza o catolicismo latino-americano até os nossos dias, avalia Paul Freston. ${ }^{28}$

Cerca de $80 \%$ das paróquias existentes no Brasil foram organizadas no século XX, sendo $50 \%$ a partir da década de 1950 . As paróquias cobrem imensos territórios e assistem uma grande população. Enquanto na França uma paróquia tem uma área territorial média de $15 \mathrm{~km} 2$ e cerca de 1.283 fiéis, na América do Sul esses números saltam para mil km2 e 14.036 pessoas.

Difundiu-se, em consequência, a figura da "Desobriga". O sacerdote percorria as vastas terras sob sua responsabilidade, "desobrigando" os fiéis de seus compromissos canônicos: batizava, casava, pregava, regularizava as situações e partia para a aldeia seguinte. Os fiéis ficavam e o padre passava. Configurou-se, assim, um tipo de catolicismo que se caracteriza, como se diz, por "pouco padre, pouca missa e muita festa" 29 . Pouco padre e pouca missa implicam pouco controle doutrinal.

$\mathrm{Na}$ prática, os católicos brasileiros orientaram a sua devoção pelo ritmo do calendário litúrgico. Com ou sem padre, todo dia é dia de santo, ensejando festejos próprios a cada devoção particular. Oratórios domésticos, capelas de beira de estrada, procissões, romarias, promessas, a reza do Terço, irmandades, podiam ser animados sob lideranças leigas, capitaneadas pelos festeiros do lugar. ${ }^{30}$

Conforme Adilson Schultz:

A matriz religiosa brasileira tem como principais referências as significações religiosas oriundas do catolicismo, das religiões afro-brasileiras e do espiritismo - além das significações indígenas naquilo que elas têm de influência sobre umbanda, espiritismo e candomblé. Forjada num intrincado e lento processo histórico, essa nebulosa paira sobre o país e não cessa de se repetir, num processo contínuo de ressignificação de seus valores e seus princípios ${ }^{31}$.

${ }^{27}$ FERNANDES, Rubens César. Religião pouco padre, pouca missa e muita festa. <http://www.tecsi.fea. usp.br/eventos/contecsi2004/brasilemfoco/port/artecult/religiao/apresent/apresent.htm>. Acesso em: 10 set. 2018.

28 FRESTON, Paul. Pentecostalism in Latin America. Social Compass, Louvain: Groupe de Sciences Sociales des Religions, v. 45, n. 3, 1998.

29 FERNANDES, 2018.

30 FERNANDES, 2018.

31 SCHULTZ, Adilson. Estrutura teológica do imaginário brasileiro. In: BOBSIN, Oneide et al. (Orgs.). Uma religião chamada Brasil: estudos sobre religião e contexto brasileiro. 2. ed. São Leopoldo: Oikos; Faculdades EST, 2012. p. 31 


\section{Pentecostalismo como fator de mudança na religiosidade}

Em meio a toda essa expressão de fé em terras brasileiras, surgem os evangélicos, também chamados protestantes. ${ }^{32} \mathrm{O}$ início do protestantismo no Brasil pode ser dividido em dois troncos principais: o protestantismo de imigração e o protestantismo de missão. O protestantismo de imigração está atrelado a vinda de imigrantes protestantes europeus a terras brasileiras no início do século XIX e a consequente vinda da igreja anglicana (Inglaterra) e igreja luterana (Alemanha). ${ }^{33}$ No final do século XIX chegam os missionários ligados ao que denominamos protestantismo de missão. Esses missionários vêm ao Brasil não para atender um grupo étnico específico, mas com o objetivo de converter os brasileiros ao protestantismo. Já no século XX percebe-se altos índices de participação da população em suas programações. ${ }^{34}$

Em 1910, quando chegam os primeiros missionários pentecostais, a saber: Luis Franscescon, imigrante italiano nos Estados Unidos da América, vem ao Brasil como missionário e inicia os trabalhos da Congregação Cristã no Brasil, especificamente na cidade de São Paulo ${ }^{35}$, Gunnar Vingren e Daniel Berg chegam a Belém do Pará, onde têm início os trabalhos da Igreja Assembleia de Deus em 1911. Nesse protestantismo pentecostal a mensagem de salvação é dirigida, sobretudo, aos indivíduos e às relações interpessoais. ${ }^{36}$

O texto que segue leva em consideração em sua análise o contexto do pentecostalismo a partir do desenvolvimento da Igreja Evangélica Assembleia de Deus, visto ser a maior denominação evangélica brasileira. Sendo, portanto, interessante fazer uma análise do contexto sociorreligioso brasileiro, pois é nesse solo propício a novas experiências religiosas que a mensagem pentecostal floresce. Assim não é sem razão que o Brasil é o maior movimento pentecostal do mundo. ${ }^{37}$

O processo de mudança no campo religioso brasileiro, observado principalmente a partir da década de 1970 , tem se acentuado. ${ }^{38}$ A Igreja Católica, por exemplo, é a que mais perdeu fiéis nos últimos anos. Em 1940, ano em que o quesito religião começou a fazer parte do censo do IBGE, mais de 95\% das pessoas se declaravam católicas; nos anos 1970, esse número já havia baixado para 90\%, e em 1991, quando foi observada uma maior queda, a porcentagem chegou a $83 \%$. No entanto, a quan-

${ }^{32} \mathrm{O}$ protestantismo é uma das três principais divisões do cristianismo, junto com o catolicismo e os ortodoxos. Originou-se com a Reforma Protestante no século XVI.

${ }^{33}$ REILY, Duncan Alexander. História Documental do Protestantismo no Brasil. São Paulo: ASTE, 2003. p. $47-48$.

${ }^{34}$ FRESTON, 1998, p. 337.

${ }^{35}$ MONTEIRO, Yara Nogueira. Congregação Cristã no Brasil. Estudos de Religião, v. 24, n. 39, jul./dez. 2010. p. 125.

${ }^{36}$ CONDE, Emílio. História das assembleias de Deus no Brasil. Rio de Janeiro: CPAD, 2000.

${ }^{37}$ Paul Freston define o pentecostalismo em três ondas principais: o clássico entre 1910 e 1911; o pentecostalismo mais voltado para curas e exorcismos que chega ao Brasil por volta de 1950, e os neopentecostais, após 1970, que utilizam um forte esquema de marketing e sua pregação está associada à prosperidade financeira. FRESTON, 1998.

${ }^{38}$ CAMPOS, Bernardo. Da reforma protestante à pentecostalidade da igreja. São Leopoldo: Sinodal; CLAI, 2002. 
tidade de evangélicos, que envolve diferentes congregações, como a Assembleia de Deus, com mais de 12 milhões de fiéis, cresceu de pouco mais de $2 \%$ em 1940, para 15,5\% no ano 2010. Há projeções que em 2019 a porcentagem de evangélicos tenha ultrapassado os $30 \%$ da população. ${ }^{39}$

Pesquisadore ${ }^{40}$ utilizam o termo "religião de conversão" para classificar a prática das igrejas evangélicas e com isso justifica o movimento crescente no número de fiéis dessas instituições. Um dos diferenciais entre a religião evangélica e a católica é o fato de que a primeira garante o poder divino na concretização das promessas ainda durante a vida, o que não acontece com o catolicismo. ${ }^{41}$

Essa transformação na religiosidade brasileira reforça um processo que os sociólogos denominam de individualização da sociedade. Isso porque uma pessoa não se sente mais obrigada a seguir a mesma religião dos pais, que praticamente é imposta ao indivíduo. Essa escolha passa a ser feita segundo as ideias e experiências de cada um. Essa tendência é conhecida como autonomia religiosa, quando são derrubados os tabus que impedem a troca da religião de nascença por alguma outra. ${ }^{42}$

As explicações que o pentecostalismo é o "refúgio das massas" pode ter sido interessante em contextos políticos do passado. Por exemplo, a literatura sobre o pentecostalismo no Brasil remonta à década de 1960, quando cientistas sociais, de diversos matizes teóricos, viram como um "raio no céu aberto" da secularização o crescimento do que julgavam religiões mágicas. Assim, não tardaram a surgir as primeiras teorias explicativas do fenômeno que, não obstante as vicissitudes teóricas, analisaram o pentecostalismo como uma espécie de refúgio das massas ${ }^{43}$ desamparadas no processo de transição entre a sociedade tradicional e moderna. Dessa forma, os primeiros estudos, grosso modo, propunham uma equação que associava variáveis como migração, anomia e conversão. Nesse sentido, o pentecostalismo era visto como tendo a função de adaptação do contingente populacional recém-migrado para a cidade, recriando espaços de sociabilidade aos quais estavam afeitos em seus lugares de origem.

No Pentecostalismo, o distanciamento entre homem e Deus deixa de existir, bem como a necessidade de intermediários. Não há mediação institucional nem santorial entre o fiel e a divindade. Os santos tão úteis do catolicismo se personalizam - "santos somos nós” - ou são transformados em ídolos e, como tais, são rechaçados, porque a adoração aos ídolos faz com que Deus se afaste do crente. Portanto, o pentecostalismo se caracte-

${ }^{39}$ Pesquisa realizada pelo Datafolha em 2016 informa que 29\% dos brasileiros maiores de 16 anos se declaram evangélicos. PERFIL e opinião dos evangélicos no Brasil. Datafolha, dez. 2016. Disponível em: <http://media.folha.uol.com.br/datafolha/2016/12/28/da39a3ee5e6b4b0d3255bfef95601890afd80709. pdf $>$. Acesso em: 03 jul. 2018.

40 MAFRA, Clara. Relatos compartilhados: experiências de conversão ao pentecostalismo entre Brasileiros e Portugueses. Mana, Rio de Janeiro, v. 6, n. 1, abr. 2000. Disponível em: <http://www.scielo.br/scielo. php?script=sci_arttext\&pid=S0104-93132000000100003 $>$. Acesso em: 25 ago. 2018.

${ }^{41}$ CAMPOS, Leonildo. Teatro, templo e mercado; organização e marketing de um empreendimento pentecostal. Petrópolis: Vozes; São Paulo: UMESP, 1999. p. 409ss.

${ }^{42}$ MARIANO, Ricardo. Os pentecostais e a teologia da prosperidade. Novos Estudos, São Paulo: CEBRAP, n. 44, p. 24ss, 1996.

${ }^{43}$ D’EPINAY, Christian Lalive. O refúgio das massas. Rio de Janeiro: Paz e Terra, 1970. 
riza como um fenômeno religioso que inaugura uma forma direta de relação do homem com Deus. O acesso a fonte de "verdade", o Espírito Santo", está aberto para todos. É necessário obedecer determinadas normas pela congregação para que o crente possa ter acesso direto. $^{44}$

O pentecostalismo acaba por romper com a religiosidade tradicional ao enfatizar a conversão como opção individual. Na religiosidade tradicional não há conversão. A religião é inata ao indivíduo e não fruto de uma decisão pessoal. Por exemplo, ser "médium" não é uma escolha, é um destino. Além disso, nas religiões afro-americanas, cada um nasce com o seu "santo", que não se escolhe. Em meio a uma sociedade mística, o pentecostalismo, como movimento evangélico, manteve os princípios teológicos comuns às igrejas evangélicas (o que chamamos de "eixo fixo"), no entanto conseguiu se comunicar com as "massas", pois teve a capacidade de articular a sua teologia de forma prática e compreensível aos ouvidos do brasileiro. ${ }^{45}$

\section{Universalização de uma religião e questões relacionadas à afinidade eletiva}

Após uma caminhada introdutória pela base da formação da religiosidade brasileira, suponho que: a teologia pentecostal clássica se encaixou na alma religiosa brasileira. Com isso, trouxe a realidade espiritual cristã para o seu contexto de vida diária, dando ao indivíduo a possibilidade de acesso direto a Deus e ao mundo espiritual.

Dentro do contexto doutrinário do pentecostalismo clássico da Assembleia de Deus, a individualização da fé, o incentivo à experiência pessoal caminha até o limite da Bíblia como palavra de Deus inspirada, regra de fé. A Bíblia é vista como a base da fé, e não a experiência. A experiência tem o seu lugar, no entanto precisa ser ancorada no texto sagrado, caso contrário torna-se apenas uma experiência do indivíduo, mas não pode ser parte da base doutrinária da coletividade. Ainda hoje isso é muito forte. Um exemplo claro são as palavras do Pr. Elienai Cabral, um dos teólogos do pentecostalismo clássico:

Na celebração do centenário do movimento pentecostal no Brasil, a essência de suas doutrinas é vista como a ênfase dada à liberdade de expressão espiritual mediante a manifestação dos dons do Espírito Santo. São 100 anos que trouxeram o movimento à maturidade. Essa maturidade, contudo, precisa ser passada em revista em busca de um equilíbrio doutrinário cujo fiel da balança deve ser a Bíblia Sagrada, a Palavra de Deus ${ }^{46}$.

44 BOBSIN, Oneide. Produção religiosa e significado social do pentecostalismo a partir de sua prática e representação. 1984. Dissertação (Mestrado) - Departamento de Ciências da Religião da Pontifícia Universidade Católica de São Paulo - PUC, São Paulo, 1984. p. 105.

45 MARIZ, Cecília Loreto. El pentecostalismo y el enfrentamento a la pobreza em Brasil. Guatemala: AIPRAL; CELEP, 1995. p. 209.

${ }^{46}$ CABRAL, Elienai. Teologia Pentecostal. Palestra na VI Semana de Teologia da Faculdade FAIFA. Disponível em: <http://www.faifa.com.br/home/images/stories/biblioteca/semanaassembleiana/2011/ construcao $\% 20 \mathrm{da} \% 20$ doutrina \%20pentecostal.pdf>. Acesso em: 20 jan. 2016. 
Para a compreensão do desenvolvimento do pentecostalismo clássico em terras brasileiras, a contribuição de Clifford Geertz é importante. Ele ajuda na discussão da universalização de uma religião. Esse processo, segundo Geertz,

envolve sempre dois movimentos antagônicos, ambivalentes: de um lado, para difundir um sistema universal de crença e ritual este precisa se adaptar a realidades locais; do outro, luta pela manutenção de suas diretrizes específicas, isto é, pela preservação de seus princípios, o que garante a sua identidade como religião ${ }^{47}$.

Dentro dessa perspectiva, possivelmente possa se aplicar aqui o conceito desenvolvido por Geertz, no qual ele realiza uma análise comparativa sobre o desenvolvimento do islamismo em duas culturas diferentes: Marrocos e Indonésia, concluindo que as diferenças apresentadas por uma mesma religião em lugares diferentes são geradas por tensões inerentes ao processo de universalização das religiões ${ }^{48}$, pois variam as estratégias sociais para resolver o dilema: adaptação versus preservação de princípios. Se caminhar um pouco mais e somar à compreensão de Geertz o conceito definido por Max Weber como "afinidade eletiva", pode-se supor que o desenvolvimento do pentecostalismo clássico no Brasil foi favorecido por questões sociais bem particulares da formação do povo brasileiro, que por afinidade, entre todas as possibilidades da teologia evangélica já presente, optou pelo pentecostalismo, por afinidade cultural.

Por afinidade eletiva entende-se que é

um conceito que nos permite justificar processos de interação que não dependem nem da causalidade direta, nem da relação "expressiva" entre forma e conteúdo (por exemplo, a forma religiosa como "expressão" de um conteúdo político ou social). [...] Naturalmente, a afinidade eletiva não se dá no vazio ou na placidez da espiritualidade pura: ela é favorecida (ou desfavorecida) por condições históricas ou sociais. [...] Neste sentido, uma análise em termos de afinidade eletiva é perfeitamente compatível com o reconhecimento do papel determinante das condições econômicas e sociais ${ }^{49}$.

A junção desses dois pensamentos leva ao conceito dos "dois eixos", onde há um fixo e outro móvel. O fixo seria o eixo teológico, mais definido, mais claro e comum a todos (mesmo na diversidade). O eixo móvel seria o que se aproximaria as expressões culturais do povo, como por exemplo, o estilo musical. ${ }^{50}$

${ }^{47}$ GEERTZ, Clifford. Observando o islã. São Paulo: Jorge Zahar, 2004. p. 32.

${ }^{48}$ Um fenômeno só se universaliza quando se consegue particularizar, em outras palavras, Deus fala dialetos.

${ }^{49}$ LÖWY, Michael. Redenção e utopia. São Paulo: Cia. Das Letras, 1989. p. 18. Em seu livro Jaula de Aço, Michael Löwy dedica algumas páginas (Capítulo 3) ao conceito "afinidade eletiva", que era voz corrente na época de Weber na Alemanha. Suspeita-se que o termo era de Johann Wolfgang Goethe. Em alemão Die Wahlverwandtaschaften. Michael faz um inventário de usos chegando a dez. São muitas afinidades. Citamos duas: entre uma visão religiosa e uma categoria profissional; entre uma ética religiosa racional e uma categoria comercial. Algumas obras temos no Brasil, e em português. Cf. LOWY, Michael. A Jaula de aço - Max Weber e o Marxismo Weberiano. São Paulo: Boitempo, 2014.

${ }^{50}$ ALVES, 2012, p. 63. 
No culto pentecostal o fiel participa, canta as suas músicas, tocam os seus instrumentos, as igrejas são implantadas com bandas de músicas ${ }^{51}$, a gaita no Rio Grande do Sul, a sanfona no Nordeste e o sempre presente violão. A música é a mesma culturalmente, o conteúdo é diferente, pois o eixo teológico é mantido. Possivelmente, em linguagem sociológica, a aceitação e o consequente desenvolvimento do pentecostalismo na sociedade tenham mais sentido por uma "afinidade eletiva" do que por planejamento por parte de seus fundadores no Brasil.

É digno de nota, no caso dos membros da Assembleia de Deus, citar que o indivíduo ao chegar à cidade, acompanhando a urbanização do país, indo participar de uma comunidade pentecostal, também assumia laços de "pertença". Pertencendo a esse grupo, todo membro de uma igreja Assembleia de Deus, ao viajar a uma outra cidade, mesmo a outro estado, portando uma "carta de recomendação" da igreja de origem, é recebido como alguém da "família da fé". Ao chegar a essa nova cidade, mesmo em um contexto cultural diferente, onde o "eixo móvel" se moveu para se aproximar da cultural local, encontra, por outro lado, o "eixo teológico" fixo mantido nos hinos da Harpa Cristã, nas práticas litúrgicas fundamentais (Santa Ceia, batismo, cultos de oração e ensino, escola dominical, grupos de jovens, círculo de oração e obreiros, por exemplo).

\section{Considerações finais}

Na busca de uma compreensão mais abrangente do crescimento do pentecostalismo, caminhou-se em busca das influências na formação da sociedade brasileira no seu início. A fé propagada pelos ibéricos era o catolicismo medieval, catolicismo este que foi aplicado na colônia brasileira. Ou seja, aqui foi implantado um catolicismo medieval, que foi contestado pelos Reformadores na Europa. Outro problema é que não se encontra no Brasil, nos três primeiros séculos, nem imprensa nem universidades, o que significa dizer que não havia livros, ou os poucos que existiam estavam muito bem guardados com as famílias nobres. Como consequência disso, vive-se um cristianismo sem livros, que em pouco tempo se tornou uma religião sem fundamentos.

A Vulgata, ou a sua tradução, era a única Bíblia autorizada pela igreja. Em alguns casos, a leitura da Bíblia era permitida sob a supervisão do padre. ${ }^{52}$ É preciso que se compreenda que o catolicismo aqui implantado pela colonização ibérica não foi propriamente o catolicismo dos padres missionários, mas das aldeias portuguesas e espanholas, com os mais variados tipos de pessoas ${ }^{53}$, e todo o sincretismo religioso que os acompanhava.

51 Essas bandas de músicas são verdadeiras fanfarras. Deve-se lembrar que no início do século XX, por exemplo, as marchinhas de carnaval eram tocadas por bandas de instrumentos de sopro e percussão.

52 NÚÑEZ, Emilio Antonio. Espiritualidade e Oração no Catolicismo e Evangelicalismo da América Latina. Vox Scripturae, ed. 35, v. 2, n. 2, 1992. p. 55. Disponível em: <http://vox.flt.edu.br/edicao/35/volume-iinumero-2-setembro-1992>.

53 Os brancos que para cá vieram eram, com raras exceções, pessoas de baixo padrão moral. Bom número era de degredados, desterrados e desertores. Outros eram náufragos e colonos, ávidos de enriquecimento rápido. Os jesuítas diziam que eles se portavam segundo a "lei natural". 
Como se percebe, essa religiosidade popular está carregada de elementos, costumes e práticas que atravessaram os séculos, herança dos colonizadores e dos povos que por aqui estiveram, tais como índios, ibéricos e africanos. A religiosidade popular é uma encarnação diversa daquela oficial romana. Dentro de um universo simbólico e de uma linguagem e gramática diferente, exatamente aquelas peculiares aos populares, esse constitui um sistema diferente de tradução do cristianismo dentro de condições concretas da vida humana.

É justamente dentro dessa população que possui um sistema diferente de compreensão (tradução) do cristianismo oficial romano que o pentecostalismo floresce. A questão a ser observada é o equilíbrio que parece ter havido entre os dois eixos, fixo e móvel. Com o passar dos anos (107 anos), parece que em muitas questões o pentecostalismo começa a abrir mão de um dos dois eixos. Ao que parece, por exemplo, o neopentecostalismo abriu mão do eixo fixo, mais consistente teologicamente, e se apegou ao eixo móvel, que gera uma assimilação cultural sem muito (ou nenhum) filtro, minimizando a importância de uma teologia bíblica exegética ancorada nas Escrituras e não na experiência. Produzindo a cada dia modelos de acordo com o "mercado consumidor religioso". Por outro lado, também se percebe que há um movimento contrário, no qual o apego ao eixo fixo produz uma rejeição ao eixo móvel, ou seja, perde-se a relevância cultural, a capacidade de ser compreendido na sua geração, inclusive sacralizando métodos, ou formas, como se fosse a única maneira possível de se comunicar a fé. O desafio permanece o mesmo, equilibrar-se a partir dos dois eixos: o fixo que sustenta as doutrinas basilares no qual o móvel se moverá em direção à cultura.

\section{Referências}

A BÍBLIA Sagrada. Tradução de João Ferreira de Almeida. Suplemento 100 anos da Assembleia de Deus. São Paulo: SBB, 2011.

ALENCAR, Gedeon. Protestantismo tupiniquim: hipóteses sobre a (não) contribuição evangélica à cultura brasileira. São Paulo: Arte Editorial, 2007.

ALVES, Eduardo Leandro. Brasil: um país de fé. Por que o Maior país católico do mundo também é o maior pais pentecostal? 2012. Dissertação (Mestrado) - Faculdades EST, São Leopoldo, 2012. ALVES, Ângela Reiner. A formação do catolicismo popular brasileiro. 2009. TCC (Licenciatura em História) - Universidade Estadual do Vale do Acaraú, Campus João Pessoa, 2009.

BATISDE, Roger. As religiões africanas no Brasil. São Paulo: Pioneira, 1971.

BOBSIN, Oneide. Produção religiosa e significação social do pentecostalismo a partir da sua prática e representação. 1984. Dissertação (Mestrado) - Departamento de Ciências da Religião da Pontifícia Universidade Católica de São Paulo - PUC, São Paulo, 1984.

. Correntes Religiosas e globalização. 2. ed. São Leopoldo: IEPG; CEBI; PPL, 2006.

BRAGATO, Fernanda. Raízes históricas dos direitos humanos na conquista da América: o protagonismo de Bartolomé de Las Casas e da Escola de Salamanca. Revista do Instituto Humanitas Unisinos, São Leopoldo, v. 487, 2016. Disponível em <http://www.ihuonline.unisinos.br/index. php?option $=$ com_content\&view $=$ article $\& i d=6495 \&$ secao $=487>$. Acesso em: 02 fev. 2019.

CABRAL, Elienai. Teologia Pentecostal. Palestra na VI Semana de Teologia da Faculdade FAIFA. Disponível em: <http://www.faifa.com.br/home/images/stories/biblioteca/semanaassembleiana/2011/construcao\%20da\%20doutrina\%20pentecostal.pdf $>$. Acesso em: 20 jan. 2018. CÂMARA CASCUDO, Luiz. Mouros, judeus e franceses. Rio de Janeiro: Perspectiva, 1984. 
CAMPOS Jr., Luís de Castro. Pentecostalismo: sentidos da palavra divina. São Paulo: Ática, 1995. CAMPOS, Bernardo. Da reforma protestante à pentecostalidade da igreja. São Leopoldo: Sinodal; CLAI, 2002.

CAMPOS, Leonildo. Teatro, templo e mercado; organização e marketing de um empreendimento pentecostal. Petrópolis: Vozes; São Paulo: UMESP, 1999.

CONDE, Emílio. História das Assembléias de Deus no Brasil. Rio de Janeiro: CPAD, 2000.

DAMATTA, Roberto. O que faz do Brasil, Brasil? 11. ed. Rio de Janeiro: Rocco, 2000.

D'EPINAY, Christian Lalive. O refúgio das massas. Rio de Janeiro: Paz e Terra, 1970.

PRADO, J. Caio. Formação do Brasil Contemporâneo. Colônia. 10. ed. São Paulo: Brasiliense. 1992.

FERNANDES, Rubens César. Religião Pouco Padre, Pouca Missa e Muita Festa. Disponível em:

$<$ http://www.tecsi.fea.usp.br/eventos/contecsi2004/brasilemfoco/port/artecult/religiao/apresent/ apresent.htm>. Acesso em: 10 set. 2018.

FREYRE, Gilberto. Casa-grande e Senzala. 28. ed. Rio de Janeiro: Record, 1992.

FRESTON, Paul. Pentecostalism in Latin America. Social Compass, Louvain: Groupe de Sciences Sociales des Religions, v. 45, n. 3, 1998.

GEERTZ, Clifford. Observando o islã. São Paulo: Jorge Zahar, 2004 .

HOLANDA, Sérgio Buarque de. Raizes do Brasil. 26. ed. Rio de Janeiro: Companhia das Letras, 1995.

JANCSÓ, István; KANTOR, Iris (Orgs.). Festa: Cultura e Sociablidade Portuguesa. São Paulo: Hucitec; Editora da Universidade de São Paulo; Fapesp: Imprensa Oficial, 2001. v. 1.

LÖWY, Michael. Redenção e utopia. São Paulo: Cia. Das Letras, 1989.

. A jaula de aço - Max Weber e o Marxismo Weberiano. São Paulo: Boitempo, 2014.

MAFRA, Clara. Relatos compartilhados: experiências de conversão ao pentecostalismo entre Brasileiros e Portugueses. Mana, v. 6, n. 1, abr. 2000. Disponível em: <http:/www.scielo.br/ scielo.php?script=sci arttext\&pid=S0104-93132000000100003 $>$. Acesso em: 25 ago. 2018.

MARIANO, Ricardo. Os pentecostais e a teologia da prosperidade. Novos Estudos, São Paulo: CEBRAP, n. 44, 1996.

MARIZ, Cecília Loreto. El pentecostalismo y el enfrentamento a la pobreza en Brasil. Guatemala: AIPRAL; CELEP, 1995.

MONTEIRO, Yara Nogueira. Congregação Cristã no Brasil. Estudos de Religião, v. 24, n. 39, jul./dez. 2010.

MOURA, Clóvis. Os quilombos e a rebelião negra. São Paulo: Brasiliense, 1981.

NÚÑEZ, Emílio Antonio. Espiritualidade e Oração no Catolicismo e Evangelicalismo da América Latina. Vox Scripturae, v. 2, n. 2, set. 1992.

PERFIL e opinião dos evangélicos no Brasil. Datafolha, dez. 2016. Disponível em: $<$ http:// media.folha.uol.com.br/datafolha/2016/12/28/da39a3ee5e6b4b0d3255bfef95601890afd80709. pdf>. Acesso em: 03 jul. 2018.

REILY, Duncan Alexander. História Documental do Protestantismo no Brasil. São Paulo: ASTE, 2003.

RIBEIRO, Darcy. O povo brasileiro - formação e o sentido do Brasil. São Paulo: Companhia das Letras, 1995.

Os Brasileiros: Livro I - Teoria do Brasil. Petrópolis: Vozes, 1978.

SARAIVA, José Hermano. História concisa de Portugal. Lisboa: Publicações Europa-América, 1984. (Coleção Saber).

SCHULTZ, Adilson. Estrutura teológica do imaginário brasileiro. In: BOBSIN, Oneide et al. (Orgs.). Uma religião chamada Brasil: estudos sobre religião e contexto brasileiro. 2. ed. São Leopoldo: Oikos; Faculdades EST, 2012.

SIEPIERKI, Carlos Tadeu. De bem com a vida: o sagrado em um mundo em transformação. 2001. Tese (Doutorado) - Programa de Doutorado na Universidade de São Paulo - USP, São Paulo, 2001. 